GSA Data Repository 2020018

Bojanowski, M.J., et al., 2020, Pedogenic siderites fossilizing Ediacaran soil microorganisms on the Baltica paleocontinent: Geology, v. 48, https://doi.org/10.1130/G46746.1

\title{
Description of the material
}

Material for this study was selected from over six hundred samples representing the Ediacaran (Volyn, Redkino and Kotlin series) and Cambrian siliciclastic rocks, mostly mudstones. They were collected from 44 wells and 18 outcrops, located in the western area of the East European Craton (Arkhangelsk region, St. Petersburg region, Estonia, Lithuania, Belarus, Poland, Ukraine and Moldova). All samples were inspected by the quantitative XRD. Many of them are red-colored rocks that contain hematite and are siderite-free. Siderite was identified only in reduced greenish to gray rocks, where hematite is usually absent or insignificant. Some samples were concretions chiefly composed of siderite. Samples with $>1 \%$ siderite were further inspected: stable $\mathrm{C}$ and $\mathrm{O}$ isotope analysis, organic geochemical investigations and optical microscopy and SEM on thin sections, were performed (Tab. A1). Evident pedogenic siderite was detected in three areas: St. Petersburg, Lithuania and eastern Belarus (Fig. 1B), representing northern and central parts of the Ediacaran sedimentary basin (Rozanov and Łydka, 1987). Siderite is rare in Lithuania, while in several profiles of the St. Petersburg area and eastern Belarus it is present in most of the Ediacaran samples above the Volyn series (Tab. A1). Average mineral contents were calculated for the St. Petersburg and eastern Belarus sections, where statistically significant number (102) of reduced gray-green samples with and without siderite was available. The sideritic samples are clearly enriched in kaolinite and fluoroapatite, whereas depleted in hematite, plagioclases and berthierine relative to the siderite-free samples. Significant differences were not observed for other minerals.

The most complete section with pedogenic siderites is from Bogushevsk-1 well (Makhnach et al., 2001), where they begin to occur in the uppermost part of the Volyn series 
(Fig. S1). The greatest abundance is, however, in the Kotlin series. Pedogenic siderites were detected in eight horizons (out of twenty six sampled) within the top $200 \mathrm{~m}$ of the Ediacaran in this well (Fig. S1).

Biomarker indices based on $\boldsymbol{n}$-alkanes, hopanes, and steranes

\begin{tabular}{|l|l|l|l|l|l|l|}
\hline \multirow{2}{*}{ Location area \& well name } & \multirow{2}{*}{ Sample No. } & \multicolumn{2}{|c|}{$n$-alkanes } & Hopanes & Steranes & \multirow{2}{*}{ S/H } \\
\hline & & CPI & TAR & C31 S/(S+R) & C27/C29 & \\
\hline St. Petersburg, Russia & & & & & & \\
\hline
\end{tabular}

$C P I=\frac{C 17+2(C 19+C 21+C 23+\cdots+C 31)}{2(C 18+C 20+C 22+\cdots+C 30)}$, in $m / z 71$ chromatogram

$T A R=\frac{(\mathrm{C} 27+\mathrm{C} 29+\mathrm{C} 31)}{(\mathrm{C} 15+\mathrm{C} 17+\mathrm{C} 19)}$, in $m / z 71$ chromatogram

$S / H=\frac{(C 27 \alpha \alpha \alpha S+C 27 \alpha \alpha \alpha R+C 28 \alpha \alpha \alpha S+C 29 \alpha \alpha \alpha S+C 29 \alpha \alpha \alpha R)}{(C 29 \alpha \beta+C 29 \beta \alpha+C 30 \alpha \beta+C 30 \beta \alpha+C 31 \alpha \beta S+C 31 \alpha \beta R+C 30 \beta \beta+C 31 \beta \alpha+C 31 \beta \beta)}$, in $m / z 191$ for hopanes and $m / z 217$ for steranes chromatograms.

Carbon Preference Index (CPI), refers to odd-over-even predominance (OEP) of numbers of $\mathrm{C}$ atoms in $n$-alkanes. Terrigenous $\mathrm{OM}$ is characterized by high values $(>>1.0)$ of this parameter (Peters et al., 2005).

A predominance of long-chained odd-numbered $n$-alkanes $\left(\mathrm{C}_{27}, \mathrm{C}_{29}\right.$, and $\left.\mathrm{C}_{31}\right)$ characterize higher plants, while short-chained odd-numbered n-alkanes $\left(\mathrm{C}_{15}, \mathrm{C}_{17}\right.$, and $\left.\mathrm{C}_{19}\right)$ indicate 
aquatic sources of OM. High values of the Terrestrial (Terrigenous)/Aquatic Ratio (TAR) shows the predominance of terrestrial-type OM (Bourbonniere and Meyers, 1996).

Hopanes have origins in bacteriohopanepolyols (BHPs), compounds contained in the lipid cell membranes of bacteria, while steranes are sterols derivatives and originated from eucariotic organisms (Peters et al., 2005). Low Sterane/Hopane Ratio (S/H) shows predominant input of prokaryotic organisms in OM.

Homohopanes are molecules which include carbon atoms from $\mathrm{C}_{31}$ to $\mathrm{C}_{35}$ with extended side chains, which isomerise at C-22 into two epimers, $22 \mathrm{~S}$ and $22 \mathrm{R}$. Biologically produced BHPs are characterised by the $22 \mathrm{R}$ configuration, which is converted gradually to $22 \mathrm{~S}$ diastereomers during diagenesis. Equilibrium of the $22 \mathrm{~S} /(22 \mathrm{~S}+22 \mathrm{R})$ ratio is achieved at $\sim 0.5-0.6$ (Peters et al., 2005). The lower values of $\mathbf{C}_{\mathbf{3 1}} \mathbf{S} /(\mathbf{S}+\mathbf{R})$ ratio characterize the immature sample, below the oil window stage of OM maturation.

For the Precambrian and Palaeozoic source-rocks predominance of $\mathrm{C}_{27}$ steranes (cholestanes) is characteristic for red algae while $\mathrm{C}_{29}$ steranes (stigmastanes) for green algae (Schwark and Empt, 2006). Hence, low $\mathbf{C}_{27} / \mathbf{C}_{29}$ ratio indicates predominance of green, photosynthetic algae.

\section{References:}

Bourbonniere, R.A., and Meyers P.A., 1996, Sedimentary geolipid records of historical changes in the watersheds and productivities of Lakes Ontario and Erie: Limnol. Oceanogr., v. 41, p. 352-359, doi: https://doi.org/10.4319/lo.1996.41.2.0352

Makhnach, A.S., Garetskiy, R.G., Matveev, A.V., and Anoshko, Ya.I., 2001, Geology of Belarus: Institute of Geological Sciences, Minsk (in Russian).

Peters, K.E., Walters, C.C., and Moldowan, J.M., 2005, The biomarker guide. Vol. 2: Cambridge University Press, Cambridge. 
Rozanov, A.Yu. and Łydka, K., 1987, Paleogeography and Lithology of the Vendian and Cambrian of the western East European Platform: Wydawnictwa Geologiczne, Warsaw. Schwark, L., Empt, P., 2006, Sterane biomarkers as indicators of palaeozoic algal evolution and extinction events. Palaeogeogr. Palaeoclimatol. Palaeoecol. v. 240, p. 225-236. doi: https://doi.org/10.1016/j.palaeo.2006.03.050

\section{Supplementary Figure Captions}

Figure DR1. Litholog of the Ediacaran strata in Bogushevsk-1 well with locations of samples containing pedogenic siderite. Lithology compiled from own investigations on the available core, the description of Bogushevsk-1 well supplied by Oksana Kuzmenkova (Research and Production Center for Geology, Minsk, Belarus) and the nearby (Fig. 1B) Bogushevsk-2 well (Makhnach et al., 2001). Dev. - Devonian, Mesop. Mesoproterozoic.

Figure DR2. Elemental composition of siderite cement. A: Results of EDS analyses (in mol\%) for S1 and S2 siderite generations in sphaerosiderites and microcrystalline cements. B: WDS mapping illustrating major differences between S1 and S2 siderite generations in microcrystalline cement (sample Bog-8A). S1 contains $\mathrm{P}$ and is Mg-poor, whereas S2 is P-free and Mg-rich, which is observed in all samples. Mn content is slightly higher in S1 in this case, but it may differ in other samples. Ap- fluorapatite.

Figure DR3. Partial mass chromatogram $(\mathrm{m} / \mathrm{z} 117)$ of L-46 sample showing the distribution of high molecular weight $n$-carboxylic acids with even-over-odd homologues preponderance. Numbers above peaks represent the number of $\mathrm{C}$ atoms in the molecule.

Figure DR4. Partial chromatograms $(\mathrm{m} / \mathrm{z} 71)$ showing preponderance of long chain odd-carbon-number $n$ alkanes from siderite-bearing and surrounding siderite-free samples from Avloga well. Numbers above peaks denote number of carbon atoms in the molecule. $\mathrm{Pr}$ - pristine; $\mathrm{Ph}$ - phytane. 


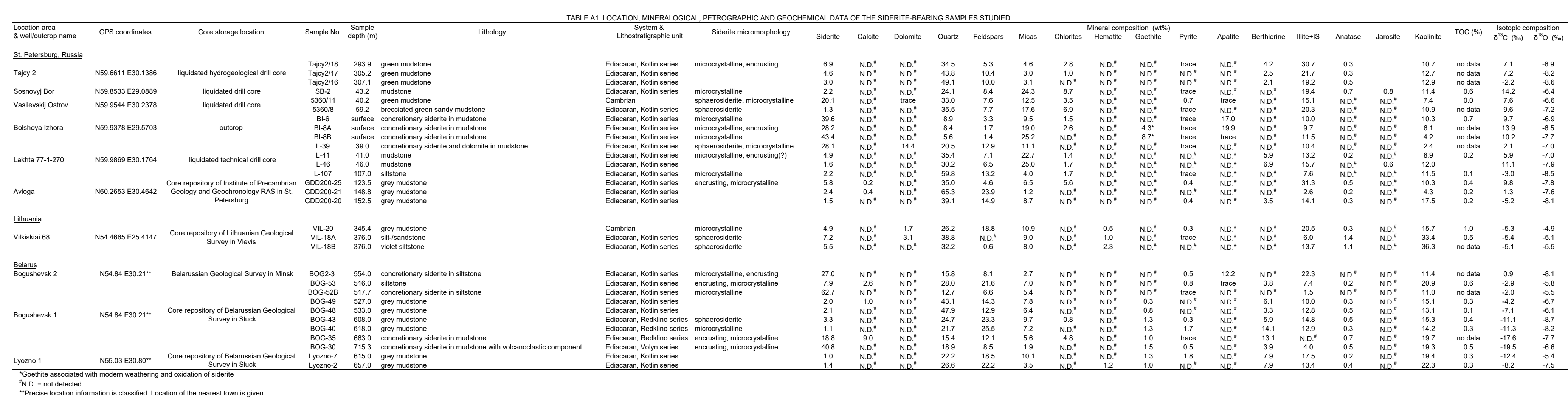


Fig. DR1

\begin{tabular}{|c|c|c|c|c|c|}
\hline 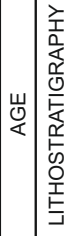 & $\begin{array}{l}\bar{\xi} \\
\underline{\underline{I}} \\
\underline{\underline{U}}\end{array}$ & LITHOLOGY & 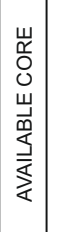 & & 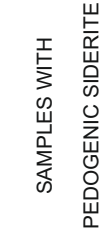 \\
\hline
\end{tabular}

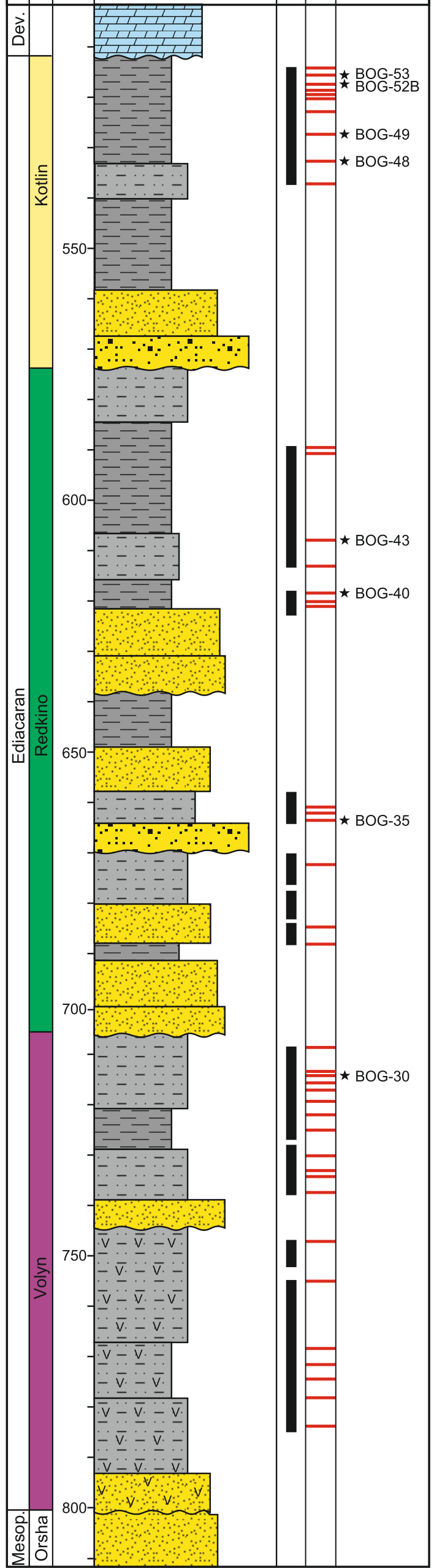

Lithologies:

$\because \because$ Gravelstone $\therefore \cdots$ Gravelstone

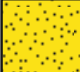
Sandstone

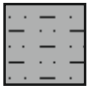

Siltstone

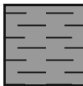

Claystone

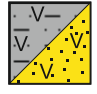

Tuffite 
Fig. DR2

A
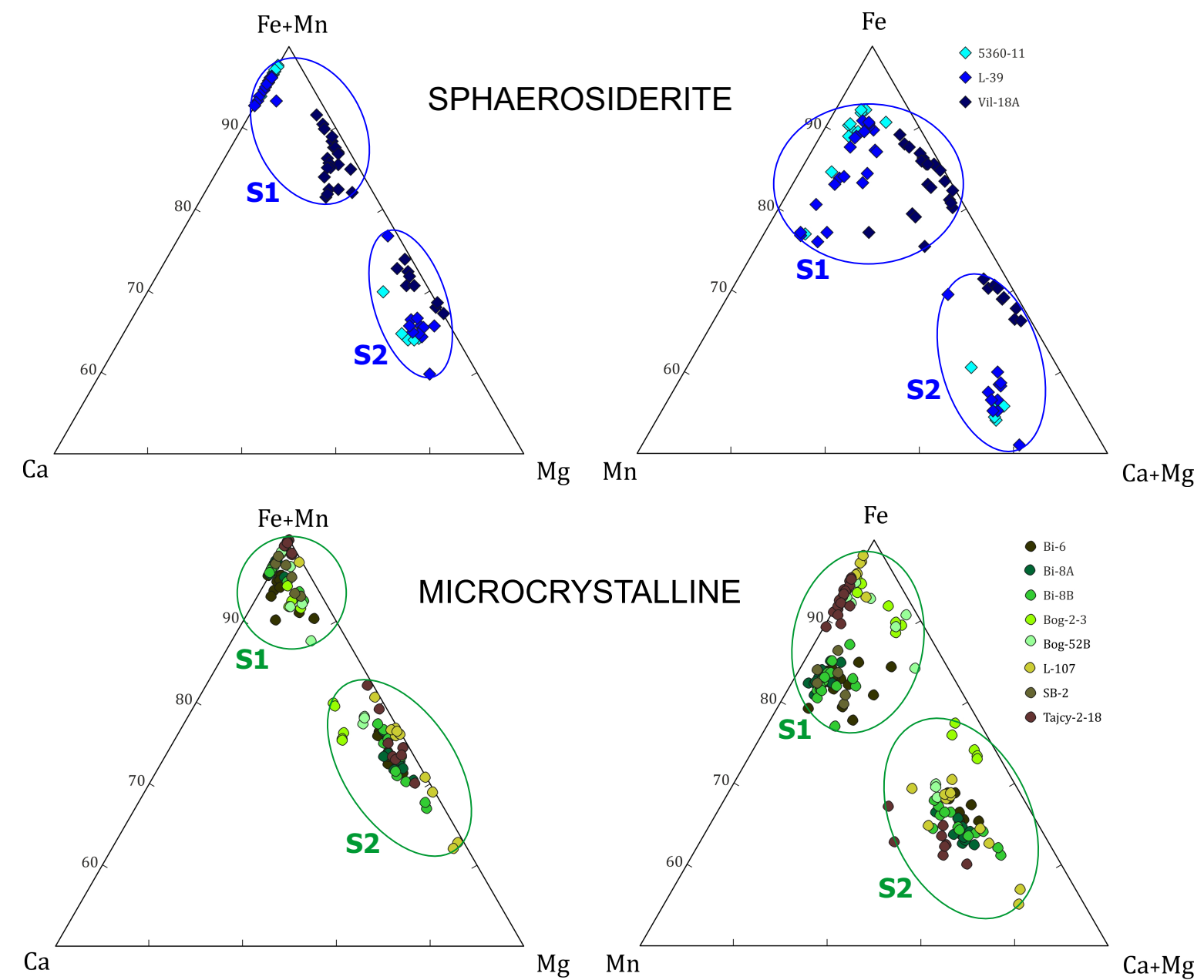

B
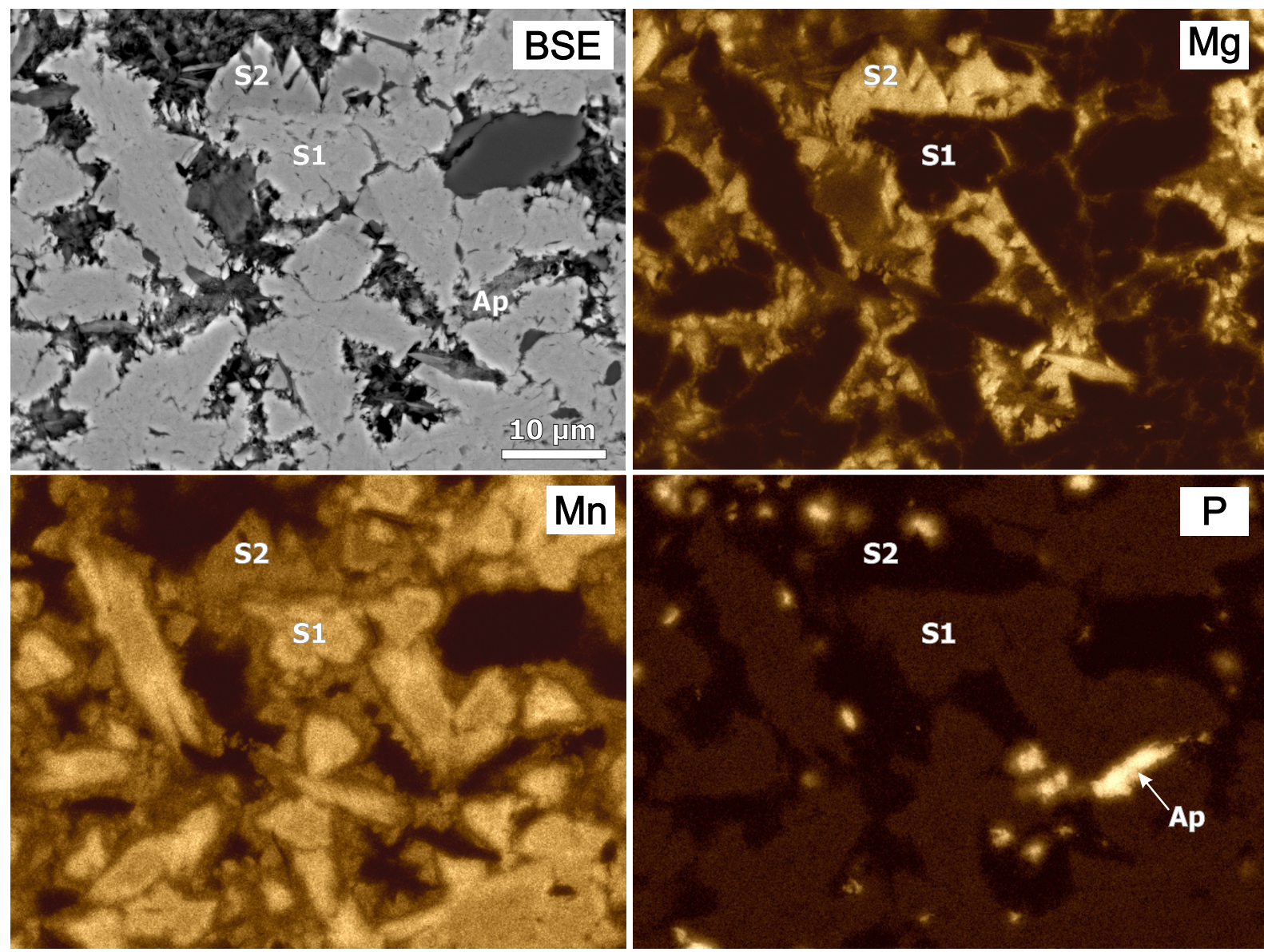
Fig. DR3

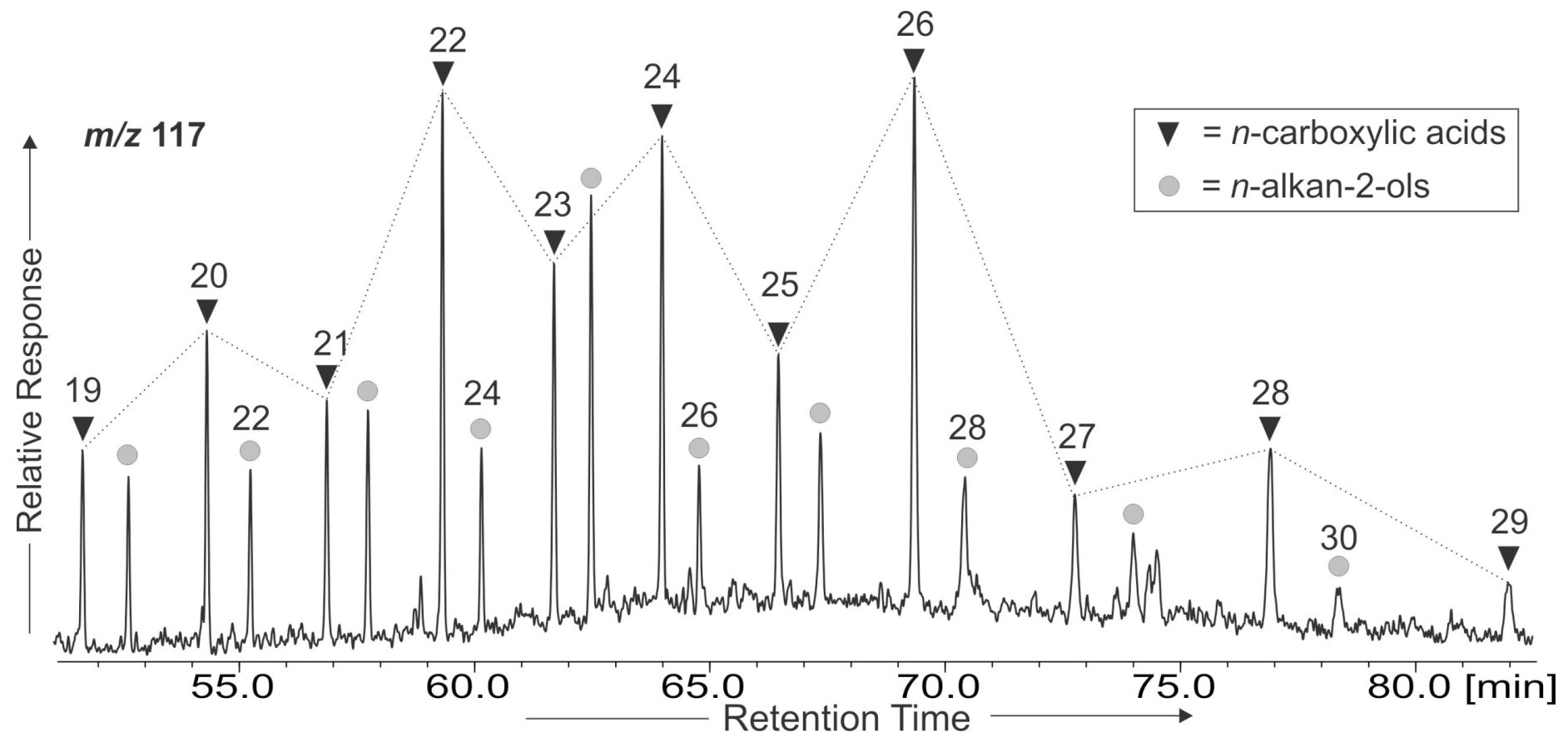


Fig. DR4

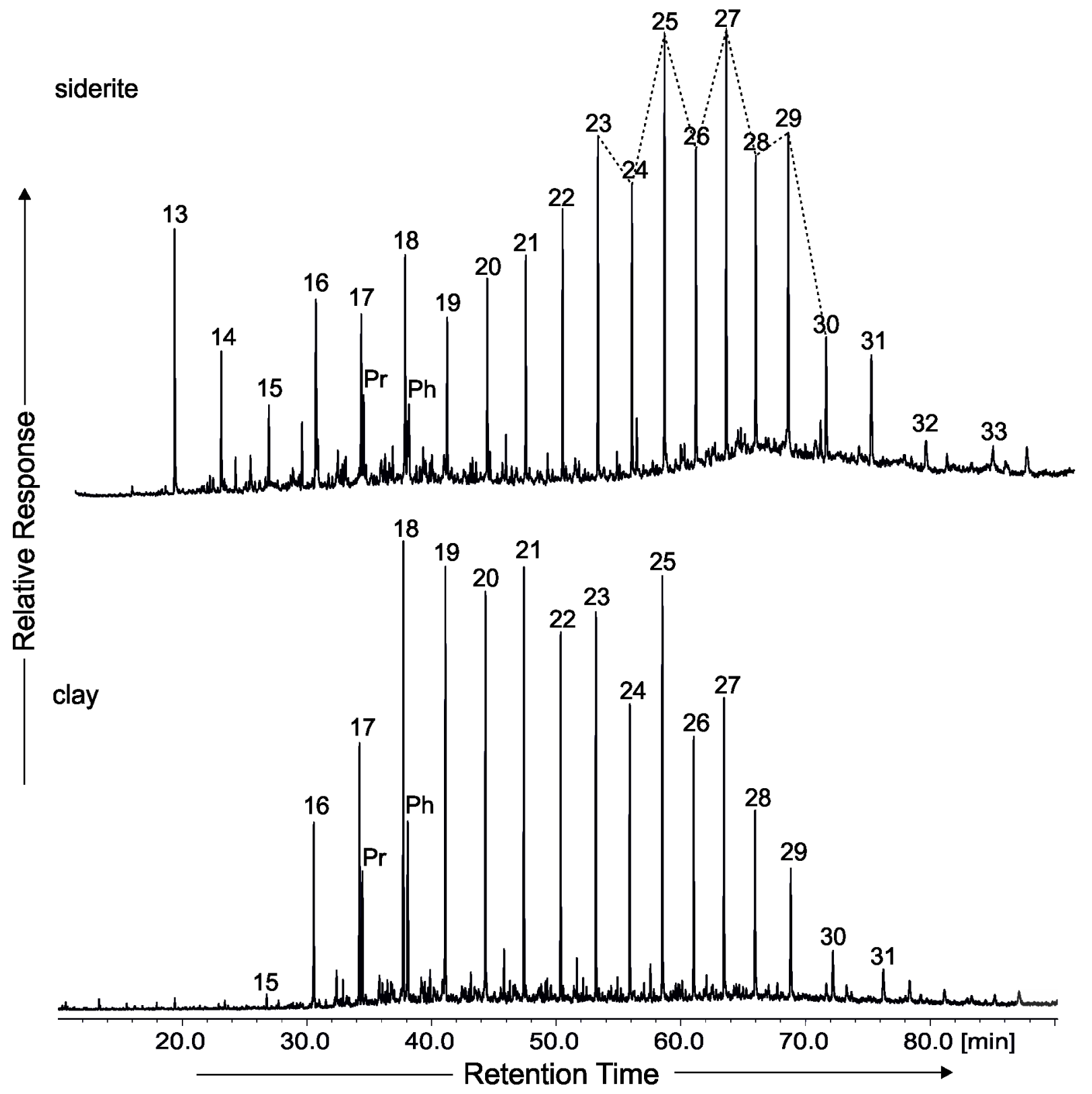

